\title{
Young immersion learners' language use outside the classroom in a minority language context
}

\author{
Pádraig Ó Duibhir \& Laoise Ní Thuairisg \\ Dublin City University
}

There has been a long history of early Irish language learning in Ireland as a result of Government policy to promote greater use of Irish. All children learn Irish in school from age 4-18 years. The majority learn Irish as a subject, typically for 30-40 minutes per day, and the levels of competence achieved are mostly disappointing. Approximately $6.7 \%$ of primary school children learn Irish in an immersion context, however, and these children achieve a high standard of communicative competence. In this paper we examine the impact of Government policy on the transfer of linguistic competence from the classroom to wider society in the context of a minority language that is becoming increasingly marginalised. We draw on data from three studies to explore the relationship between Irish-medium school attendance and the desire and opportunity to use Irish outside of school while attending school, and later as an adult. The first study also investigated students' attitudes towards learning and using Irish. All three studies examined parents use of Irish in the home and the influence that the language spoken in their home during childhood and the language of their schooling had on their current language practices. Overall, Irish-medium schools are very successful in educating proficient speakers of Irish who have very positive attitudes towards Irish. These positive attitudes and proficiency do not necessarily transfer to use of Irish in the home. While attendance at an Irish-medium school as a child has a positive effect on later use of Irish, when former students become parents, the effect is quite small. The perennial challenge persists in transferring competence in a minority language acquired in school to the home and community.

Keywords: language immersion, minority language, language use, Irish 


\section{Introduction}

Early language learning, especially the learning of Irish has been a feature of the Irish education system since the foundation of the Irish Free State in 1922. Irish as a vernacular language slowly declined under British rule in the centuries prior to independence. The education policy sought to reverse the language shift of the previous two centuries and to create a bilingual society. This article explores the impact of the education policies of the Irish Free State; a key feature of which was the introduction of Irish-medium teaching, initially in the early school years for 4-6-year-olds and later throughout the school system. The relative failure of these policies by the 1970 's led in part at least, to the establishment of a parent-led movement to advocate for additional Irish-medium schools. The relative success of this movement over the last four decades occurred in the context of a decline in the level of Irish spoken throughout Ireland and especially in the Irish speaking heartland Gaeltacht communities that still survive mostly in small pockets along the west coast (Central Statistics Office, 2017; Ó Giollagáin \& Charlton, 2015). The implications of this decline of the spoken language are considered in relation to the future transmission of Irish and the fluency levels attained through Irish immersion programmes.

The language practices of Irish-medium students and their parents in the home and community environment are of central importance to the debate about the future transmission and use of Irish. This paper reports a recent study to investigate students' attitudes towards learning and using Irish and the extent to which they use Irish in school and in the wider community. The study was conducted to explore the potential for Irish-medium students to increase the use of Irish in society. The children's parents were also studied to explore if the home languages spoken by them during their childhood and the language of their schooling influenced their use of Irish with their children. We recognise that Irish-medium students are not the only source of future speakers of Irish, but given the rise in the numbers attending immersion programmes and the high levels of competence in Irish that these students achieve, they have the potential and capacity to become a significant body of new speakers of Irish. However, previous research shows that while many Irish adults have a reasonable competence in Irish only a tiny minority, about $2 \%$, are active users of the language.

\section{Irish language decline and revival}

Ireland is not alone in its efforts to revitalise its native language and to increase the level of Irish spoken in society by means of the education system (Shah \& 
Brenzinger, 2018). Other jurisdictions where this is the case include the Basque Country, Hawaii, New Zealand, Scotland and Wales. The Irish language has been in decline since the early 17th century, but the decline accelerated in the 19th century. Estimates suggest that three to four million out of a population of almost eight million in Ireland in the 183 os were Irish speakers (Wolf, 2014). By 1851, only $29.1 \%$ of the population spoke Irish (Central Statistics Office, 1932) and only about one third of these (10\%) were monoglot Irish speakers (Doyle, 2015).

The national school system established in Ireland in 1831 did not slow the decline in the number of Irish speakers, as no Irish was taught, even in areas where monoglot Irish speakers predominated. After independence when the Irish Free State was established in 1922, the education system was given a primary role in the revival of Irish. The Irish language was a unique badge of nationhood and identity. A nation that had a separate language could be seen as a distinct nation. This was a very important sentiment for many Irish people at that time as it helped them to define themselves as different from their English colonisers (Walsh, 2016).

The newly formed Irish State adopted a top-down approach to teaching Irish in schools. The first National Programme Conference (1922) advised that Irish should be the sole medium of instruction in infant/kindergarten classes and it should be used as the medium of instruction for at least one hour per day in all other classes where teachers with sufficient Irish were available (Ó Duibhir, 2018). This was the genesis of an early total immersion approach. The intention was to extend this policy as a greater number of teachers became proficient in Irish. We see resonances of this approach in some education systems today, where education ministries mandate a content and language-integrated (CLIL) approach in schools and universities without the necessary pre-service teacher training or limited professional development (Lasagabaster \& Sierra, 2010). A second National Programme Conference convened in 1925, proposed however, that English would be used as a medium of instruction prior to 10:30 in Infant classes as the initial target was seen as overambitious.

The emphasis on teaching through Irish led to a narrowing of the curriculum and the exclusion of some subjects such as science, for example (Walsh, 2012). Some parents became critical of the over emphasis on Irish as they saw it (O'Connell, 1968). By 1940 Irish was the medium of instruction in just $12 \%$ of national schools (Ó Buachalla, 1984). This represented the high point for Irish-medium education policies and there was a steady decline from the $1950 \mathrm{~s}$ onwards. Poor understanding of the complexity of language revival and language immersion programmes resulted in unrealistic expectations about what could be achieved in the short to medium term. The endeavour to achieve too much too soon may have done long-term damage. A more carefully planned approach 
which involved other state institutions and the wider public may have led to greater success and a more sustainable model. There are lessons to be learned here for governments in other jurisdictions wishing to increase CLIL approaches in school and university settings in the absence of adequate teacher training and resources (Lasagabaster \& Sierra, 2010).

A dramatic decline in the number of schools teaching through the medium of Irish occurred between the most successful period in the 1940s and the 1970 s when there were only ten Irish-medium primary schools outside the Irishspeaking Gaeltacht communities. During the 1960 s a policy shift occurred that brought an end to the official state policy for the revival of the Irish language in favour of the promotion of bilingualism in the 1970s. By this time, some parents were unhappy with the standard of Irish in English-medium schools. They wanted to ensure that their children would achieve a reasonable level of competence in Irish, and this led to the establishment of parent-led naíonraí (Irish-medium playgroups) and gaelscoileanna (Irish-medium schools). In many cases, it was the success of the naionra in a community that led to parental demand for the establishment of an Irish-medium primary school (McAdory \& Janmaat 2015; Ó Duibhir, 2018). Other minority language communities internationally have seen similar successful early childhood immersion education efforts lead to the establishment of immersion primary and post-primary schools.

There has been significant growth in the number of Irish-medium schools in Ireland (Northern Ireland and Republic of Ireland) since the 1970s, as shown in Figure 1. There were 230 Irish-medium schools on the island of Ireland in 2018-19; 180 primary and 50 post-primary schools (source: <www.gaeloideachas ie $>$ ). The overall percentage of the primary students receiving education through Irish is $6.73 \%$ (Table 1). Despite the growth trajectory of Irish-medium education (Figure 1) the potential for further growth has not been realised. Darmody and Daly (2015) found that $23 \%$ of parents in the Republic of Ireland and $12 \%$ of parents in Northern Ireland would send their child to an Irish-medium school if one opened in their area. Despite this, the Departments of Education in the Republic of Ireland and Northern Ireland have not responded to this need or capitalised on this opportunity.

Parental motivation for the choice of a primary Irish-medium education was explored in a recent study (Ní Thuairisg \& Ó Duibhir, 2016). When asked to select the reasons for their choice, just over three quarters $(76.9 \%)$ identified a desire for their child to be able to speak Irish, while $61.7 \%$ wanted their child to be bilingual. When asked their views of their child's Irish-medium education experience, $99 \%$ were satisfied, which suggests that Irish-medium schools are meeting parent's desire for their children to be able to speak Irish and become bilingual. 


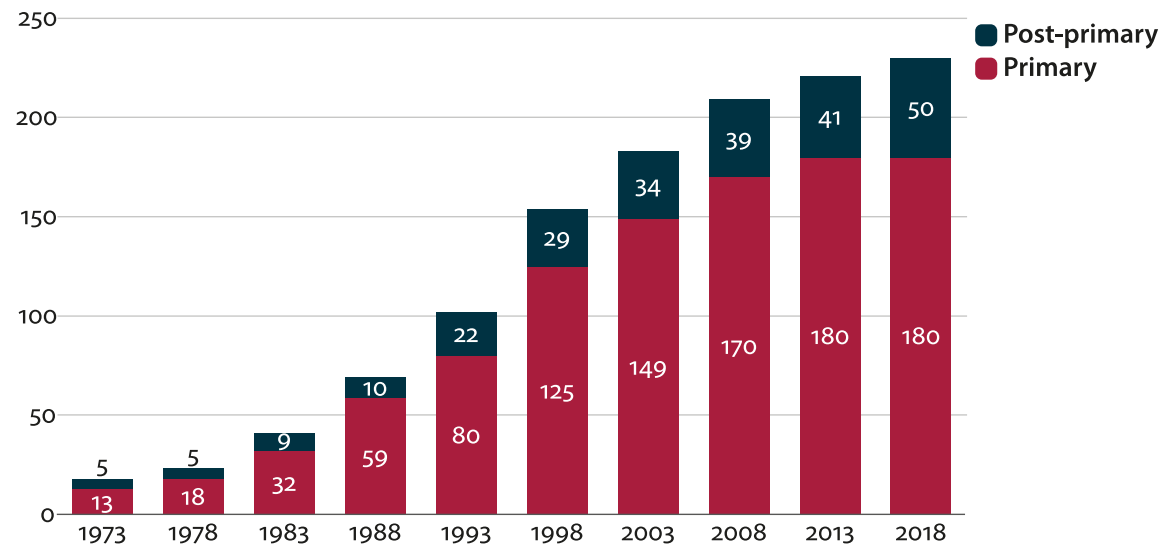

Figure 1. Growth in Irish-medium schools in Ireland 1973-2018

Table 1. Student enrolment in Irish-medium primary schools in the Republic of Ireland and Northern Ireland in the 2017-2018 school year

\begin{tabular}{lccccc}
\hline & $\begin{array}{c}\text { Republic of } \\
\text { Ireland within } \\
\text { the Gaeltacht }\end{array}$ & $\begin{array}{c}\text { Republic of } \\
\text { Ireland outside } \\
\text { the Gaeltacht }\end{array}$ & $\begin{array}{c}\text { Republic } \\
\text { of } \\
\text { Ireland } \\
\text { total }\end{array}$ & $\begin{array}{c}\text { Northern } \\
\text { Ireland }\end{array}$ & $\begin{array}{c}\text { Total for } \\
\text { island of } \\
\text { Ireland }\end{array}$ \\
\hline $\begin{array}{l}\text { Number of } \\
\text { students in Irish- } \\
\text { medium schools }\end{array}$ & 7,367 & 37,183 & 44,550 & 4,156 & 48,706 \\
$\begin{array}{l}\text { Total number of } \\
\text { primary students }\end{array}$ & 549,679 & 549,679 & 549,679 & 173,744 & 723,423 \\
Percentage & $1.34 \%$ & $6.76 \%$ & $8.10 \%$ & $2.39 \%$ & $6.73 \%$ \\
\hline
\end{tabular}

From a linguistic competency perspective, it can be argued that the Irish language policy has been partially successful over the course of the last century in so far as the percentage of people who report an ability to speak Irish increased from $18.3 \%$ in the census of 1926 to $39.8 \%$ in the 2016 census. Self-reported ability does not equate with language vitality, however. The number of active speakers of Irish is a more accurate criterion. The Irish Government recognised this fact when an ambitious target was set in the 20-year Strategy for the Irish Language 2010-2030 (20-year Strategy henceforth) to increase the number of daily speakers of Irish from 77,185 to 250,000 by 2030 (Government of Ireland, 2010). Many considered this target unrealistic at the time the strategy was launched (Ó Duibhir, 2012) and indeed, the census figures show a decline in the number of daily speakers of Irish in the period 2011 to 2016 . Furthermore, the number of people speaking Irish daily 
in the Gaeltacht decreased by 2,589 (11.2\%) between 2011 and 2016 , from 23,175 to 20,586 (Central Statistics Office, 2017). In the 20-year Strategy, similar to previous language revival policies in Ireland, the Government reiterated the central role of the education system in the revitalisation of Irish. Although the teaching and learning of Irish is promoted to varying degrees throughout the education system (Ó Laoire, 2006), it is the use of the language outside the school context that really matters to the vitality and transferability of the language. The evidence from language revitalisation efforts throughout the world, is that it is difficult to transfer a language (particularly a minority language), acquired solely within an education context, to use in wider society (Baker, 2003). The 20-year Strategy recognises the "critical need to give life to the Irish language outside the classroom" (Government of Ireland, 2010,p.22), but to date there is minimal evidence of material progress in this regard. Fishman (2013) cautioned against an over reliance on the education system to revive a language and cited Ireland as an example not to follow.

The greater use of Irish in society which is the key aspiration of the 20-year Strategy requires three interacting factors to be realised; (1) increased ability in Irish, (2) improved opportunities to use the language, and (3) the fostering of positive attitudes towards the use of Irish (Government of Ireland 2010, p. 12). These factors align with what Grin (2003) believes necessary to increase minority language use: "capacity", "opportunity" and "desire". While the 20-year Strategy aims to improve the learning of Irish within the education system, it also recognises that this will not result in greater use unless there are greater opportunities to use Irish and a positive desire to do so. Grin (2003) believes that the state must play a role in creating opportunities for Irish language use through language policies, especially in the domain of the family. Currently in Ireland, there is very little evidence of state policies to support the creation of such opportunities despite the recognition of need identified in the 20-year strategy. Evidence of the limitations of Irish acquired in school is found in a study by Ó Duibhir (2011). The 6th class Irish-medium students $(n=65)$ had little or no contact with Irish outside of school. They lived in a predominantly English-speaking world and found learning Irish difficult as a result. Nevertheless, Murtagh (2007) found that former students of Irish-medium schools were more likely to participate in Irish-language networks and to speak Irish more frequently as adults, than students who attended English-medium schools. Ó Cathalláin (2011) found that Irish-medium students whose parents were supportive of Irish or who had links with Irish-speaking heartland (Gaeltacht) areas were more motivated to speak Irish than students without such supports or connections. Student visits to Gaeltacht areas created opportunities to interact with Irish speakers and this helped affirm second language (L2) speaker identity. Darmody and Daly (2015) reported that adults were almost twice as likely to speak Irish if they had a high standard of ability (80\%) 
compared to $(43 \%)$ those who had a basic standard. In the same study, $43 \%$ of adults whose parents had a high standard of Irish, spoke it on a weekly basis compared to $6 \%$ of adults whose parents didn't have Irish. In summary, it seems that those with greater ability to speak Irish and those with opportunities to engage in Irish language activities and networks, albeit tentative, are much more likely to speak Irish weekly or more frequently.

Former students of Irish-medium schools have a reasonable standard of Irish even after primary education. It cannot be assumed, however, that they will choose to speak Irish outside of school or when they complete their schooling. Even in families where Irish is spoken, Ó Riagáin (2000) estimated in the 1990s that only about a quarter of children reared in such households, spoke Irish to their own children as adults (Ó Riagáin, 200o). He reported that Irish was spoken in three distinct family groups; (1) competent bilinguals who acquired Irish at school, (2) parents who were reared speaking Irish, and (3) parents not reared through Irish and without a strong connection to Irish at school. This third group represented parents who sent their children to Irish-medium schools and this encouraged them to speak some Irish with their children at home. Like other minority Celtic language contexts, Irish is dependent on a variety of ways to transmit the language (Ó Murchadha \& Migge, 2017).

\section{New speakers of Irish}

O'Rourke and Walsh (2015, p. 64) define new speakers as "those individuals who acquired the language outside of the home and who report that they use Irish with fluency, regularity and commitment”. A significant number of Irish people could be classified as new speakers if the definition was based on ability in Irish alone, but critically, this definition identifies not just fluency, but the use of Irish on a regular basis as well as a commitment to use Irish. New speakers come from a range of backgrounds; those who acquired Irish in school, those who were exposed to Irish in the home outside the Gaeltacht, and those who grew up in Englishspeaking homes in the Gaeltacht and were exposed to Irish in the school and the local community (Walsh, O'Rourke \& Rowland, 2015). Some new speakers consciously approximate to native speaker phonology and grammar (O'Rourke \& Walsh, 2015). Others tend to speak a non-traditional variety of the language and this can be contentious as their variety of the target language may not be accepted by traditional speakers of the language (Hornsby, 2017). Hornsby (2017) believed that an ideology of language that placed the new speaker at the centre of the discourse was preferable to one that placed the language itself at the centre. Regardless of the variety of Irish used by new speakers, they wish to affirm 
their ownership of the language and to be recognised as Irish speakers (Walsh \& O’Rourke, 2015).

Pujolar and Gonzàlez (2013,p.139) describe mudes as "specific biographical junctures where individuals enact significant changes in their linguistic repertoire". New speakers can recount these transformation points when they changed their language practices. Among the main biographical moments identified by Pujolar and Gonzàlez $(2013,143)$ are: (1) entering primary school, high school or university; (2) entering the labour market; (3) creating a new family or becoming a parent. There can be a degree of interdependence between these mudes and they need not necessarily be discreet points. The focus of this paper is to consider attendance at an Irish-medium school as a biographical moment to enact significant change in linguistic repertoire.

The variety and accuracy of Irish spoken by 6 th class students $(n=65)$ in Irish-medium schools was studied by Ó Duibhir (2011). The students displayed very good communicative ability, but non-target-like syntactic and morphological features were also present in their speech. Forty per cent of these students, in the final stages of their primary education were likely to progress to Irish medium post-primary education. (Ní Thuairisg \& Ó Duibhir, 2016). One would hope that those who transfer to Irish-medium post-primary would continue to develop their ability in Irish as a consequence of the continued contact with the language and the higher cognitive challenge of post-primary education. This further development of communicative ability in Irish of Irish-medium post primary students satisfies the "capacity" element proposed by Grin, (2003) necessary to increase minority language use.

We now turn our attention to how Grin's other elements; "opportunity" and "desire" are fostered and supported in those attending Irish medium schools. Dörnyei (2009) argued that motivation is an important element in second language (L2) learning. A positive attitude and motivation can help the learner to continue to strive to learn a language over a long period despite the inherent challenges (Harris \& Conway, 2002). These drivers of language use had not been previously studied in Ireland, so we report here on a study conducted to examine student attitudes to using Irish ("desire") and the extent to which it is possible for students to use Irish outside the classroom ("opportunity"). The children's parents were also studied to determine if home language in childhood and language of schooling influenced their use of Irish with their own children. The data from two further studies which included identical questions regarding parental influence on use of Irish were pooled with the original study to increase the sample size of the parent group and thus reduce sample bias. 


\section{Methods}

In this section the methodologies of the three related studies are described (see Figure 2). The main study (Study A) ${ }^{1}$ surveyed Irish immersion students on the island of Ireland about their motivation to learn and speak Irish and their parents about their use of Irish with their children (Ó Duibhir et al., 2017). In the subsequent studies (Studies B and C), ${ }^{2}$ one of which investigated transfer rates of students from primary to post-primary Irish-medium schools and the other which examined the impact of language immersion education on students from low socio-economic backgrounds, identical questions were asked as part of a parental survey of the parents of Irish immersion students (Ní Chlochasaigh et al., 2018). The rationale for administering the same questions to these parents was to allow additional analysis that was not possible with a smaller sample size. We wished to examine if participation in an Irish-medium education in the previous generation (of parents) impacted on the language behaviour of the current school-going generation. In doing so we acknowledge that language acquired at school is only one factor that might influence active bilingualism in adulthood. No student data relevant to this report were collected in Studies B \& C.

Table 2. Study population cohorts (students and parents) included in this report

\begin{tabular}{lcc}
\hline & Immersion students & Parents \\
\hline Study A & 373 & 346 \\
Study B & N/A & 318 \\
Study C & N/A & 395 \\
Total & $\mathbf{3 7 3}$ & $\mathbf{1 0 5 9}$ \\
\hline
\end{tabular}

In Study A students and their parents were recruited from 20 Irish-medium primary and post-primary schools spread throughout the island of Ireland using a non-random convenience sampling method. Students of similar age were recruited in both jurisdictions; 5 th Class students in the Republic of Ireland and Class 7 students in Northern Ireland. Both groups were aged 10 or 11-year olds and were close to the end of their primary education. In a similar way at post-primary level, 4th Year students in the Republic of Ireland and Year 12 students in Northern Ireland were recruited. The students in these classes were 15 or 16-years old and were selected for ease of access compared to their older peers who were preparing for terminal examinations.

1. The first study was funded by the North/South Standing Committee on Immersion Education.

2. Study B was funded by Gaeloideachas and Study C was funded by An Chomhairle um Oideachas Gaeltachta agus Gaelscolaíochta, the council for Irish-medium education. 
An Attitude/Motivation Test Battery (AMTB, see Appendix A) questionnaire was circulated to 616 students in total. The AMTB was originally developed by Gardner (1985) and modified for the Irish context initially by Harris and Murtagh (1999) and later by Ó Duibhir (2010). Students self-reported their attitudes and motivations towards learning and using Irish across 5 scales with a total of 37 items. Each item was scored using a Likert-type scale ( $1=$ 'strongly disagree' to $5=$ 'strongly agree'). The five scales were:

1. Desire to learn Irish (six items)

2. Attitude to learning Irish (seven items)

3. Parental encouragement to learn Irish (five items)

4. Irish-ability self-concept (six items)

5. Use of Irish ( 13 items)

One context within the Irish immersion system where students had opportunities to use Irish outside the classroom was in the school playground at breaktime. This context was included in the "use of Irish" scale.

Descriptive statistics were conducted to determine mean scale scores and mean student scores. Analysis of variance (ANOVA) tests were conducted to identify statistically significant differences in the scale scores across different school types and jurisdictions. Chi-squared and regression analysis were also conducted.

The student's parents in Study A were also invited to complete a questionnaire devised to examine their own use of Irish and the factors that may have influenced their choices in the regard. The questions were divided into three sections; (1) parental background (nine questions), (2) your child and Irish language use (seven questions), (3) the school and Irish-medium education (21 questions). In this report we focus on the answers given to the questions below. Identical questions were asked of parents recruited to all studies with responses of 346, 318 and 395 for studies A, B and C respectively.

\section{Linguistic background of parents}

When you were growing up what languages were spoken in your home?

i. English only

ii. English and Irish, but mostly English $\square$

iii. English and Irish, half and half

iv. English and Irish, but mostly Irish

v. Irish only

vi. Other

\section{Language medium of parental schooling}

Did you attend an Irish-medium primary school?

Yes $\square$ No $\square$ 
Did you attend an Irish-medium post-primary school?

Yes $\square$ No

\section{Parental self-reported language practice with children}

What language(s) do you speak with your child?

i. English only

ii. Mostly English with a few words/phrases in Irish $\square$

iii. English and Irish, but mostly English

iv. English and Irish, half and half

v. English and Irish, but mostly Irish

vi. Mostly Irish with a few words/phrases in English

vii. Irish only

viii. Other

If other, please specify.

\section{Results}

The results of the studies are presented in three sections. The first section relates to the student AMTB results in Study A. The second section will look at the results of the parental questions across the three studies (A, B \& C). The final set of results will report correlations between the student and parental results in study A.

\section{AMTB results}

The AMTB yielded an overall response rate of $60.1 \%(n=373)$. The mean AMTB scale scores for each group are presented in Table 3. The item mean scores per student are shown in brackets.

The 'Desire to learn Irish' scores were similar for all school types. The primary students in Northern Ireland had the highest scores for the 'Attitude to learning Irish' scale (30.28) and there was a statistically significant difference between these students and the post-primary students in both the Republic of Ireland and Northern Ireland for this scale. In relation to 'Parental encouragement to learn Irish', there was a statistically significant difference between the post-primary students in Northern Ireland who had the highest mean score (19.97) and the post-primary students in the Republic of Ireland who had the lowest mean score (16.55). No statistically significant differences were seen between the student groups in the 'Irish ability self-concept' mean scores. Finally, the total scores for primary students in both jurisdictions were significantly 
higher than those of the post-primary students. Overall, the mean scores per student were highest for 'Attitude to learning Irish' (4.1) and lowest for 'Use of Irish' (3.1).

Table 3. Student group and AMTB mean scores per scale by school type (average mean scores in brackets) ${ }^{*}$

\begin{tabular}{|c|c|c|c|c|c|c|}
\hline & & $\begin{array}{c}\text { Desire to } \\
\text { learn } \\
\text { Irish }\end{array}$ & $\begin{array}{c}\text { Attitude } \\
\text { to } \\
\text { learning } \\
\text { Irish }\end{array}$ & $\begin{array}{c}\text { Parental } \\
\text { encouragement } \\
\text { to learn Irish }\end{array}$ & $\begin{array}{c}\text { Irish } \\
\text { ability } \\
\text { self- } \\
\text { concept }\end{array}$ & $\begin{array}{l}\text { Use of } \\
\text { Irish }\end{array}$ \\
\hline $\begin{array}{l}\text { School type } \\
\text { (jurisdiction) }\end{array}$ & $\begin{array}{c}\text { No. of } \\
\text { participants }\end{array}$ & $\begin{array}{c}6 \text { items } \\
(30 \\
\text { points }) \\
\text { alpha } \\
0.75\end{array}$ & $\begin{array}{c}7 \text { items } \\
(35 \\
\text { points }) \\
\text { alpha } \\
0.83\end{array}$ & $\begin{array}{c}5 \text { items ( } 25 \\
\text { points) alpha } \\
0.70\end{array}$ & $\begin{array}{c}6 \text { items } \\
(30 \\
\text { points }) \\
\text { alpha } \\
0.68\end{array}$ & $\begin{array}{c}13 \text { items } \\
(65 \\
\text { points }) \\
\text { alpha } \\
0.78\end{array}$ \\
\hline $\begin{array}{l}\text { Fifth-class } \\
\text { primary } \\
\text { (RoI); age } \\
\text { 10-11 years }\end{array}$ & 128 & $\begin{array}{c}22.70 \\
(3.8)\end{array}$ & $\begin{array}{c}29.13 \\
(4.2)\end{array}$ & $19.22(3.8)$ & $\begin{array}{l}21.63 \\
(3.6)\end{array}$ & $\begin{array}{l}42.66 \\
(3.3)\end{array}$ \\
\hline $\begin{array}{l}\text { Seventh-class } \\
\text { primary (NI); } \\
\text { age } 10-11 \\
\text { years }\end{array}$ & 69 & $\begin{array}{r}23.55 \\
(3.9)\end{array}$ & $\begin{array}{l}30.28 \\
(4.3)\end{array}$ & $18.45(3.7)$ & $\begin{array}{r}22.66 \\
(3.8)\end{array}$ & $\begin{array}{l}42.40 \\
(3.3)\end{array}$ \\
\hline $\begin{array}{l}\text { Year } 4 \text { post- } \\
\text { primary } \\
(\text { RoI); age } \\
15-16 \text { years }\end{array}$ & 101 & $\begin{array}{r}22.47 \\
(3.7)\end{array}$ & $\begin{array}{c}27.71 \\
(4.0)\end{array}$ & $16.55(3.3)$ & $\begin{array}{l}22.18 \\
(3.7)\end{array}$ & $36.9(2.8)$ \\
\hline $\begin{array}{l}\text { Year } 12 \text { post- } \\
\text { primary }(\mathrm{NI}) \text {; } \\
\text { age } 15-16 \\
\text { years }\end{array}$ & 75 & $\begin{array}{c}23.23 \\
(3.9)\end{array}$ & $\begin{array}{r}27.37 \\
(3.9)\end{array}$ & $19.97(4.0)$ & $\begin{array}{l}21.09 \\
(3.5)\end{array}$ & $\begin{array}{l}33.07 \\
(2.5)\end{array}$ \\
\hline Total & 373 & $\begin{array}{c}22.41 \\
(3.7)\end{array}$ & $\begin{array}{c}28.67 \\
(4.1)\end{array}$ & $17.72(3.5)$ & $\begin{array}{c}21.68 \\
(3.6)\end{array}$ & $\begin{array}{l}39.81 \\
(3.1)\end{array}$ \\
\hline
\end{tabular}

\footnotetext{
* The average mean score is calculated by dividing the scale score by the number of items in the scale.
}

In Irish immersion schools all students are expected to speak Irish throughout the entire day including break-time. Students' language behaviour within school but outside of class varied considerably. Responses to the statement "To be honest, I don't make much effort to speak Irish outside of the class when I am at school" showed that just over half $(51.2 \%)$ of the primary students and just over a quarter $(25.7 \%)$ of post-primary students disagreed or strongly disagreed with this statement (Figure 2). This suggested that post-primary students made less effort to speak Irish while in school but outside of class. 


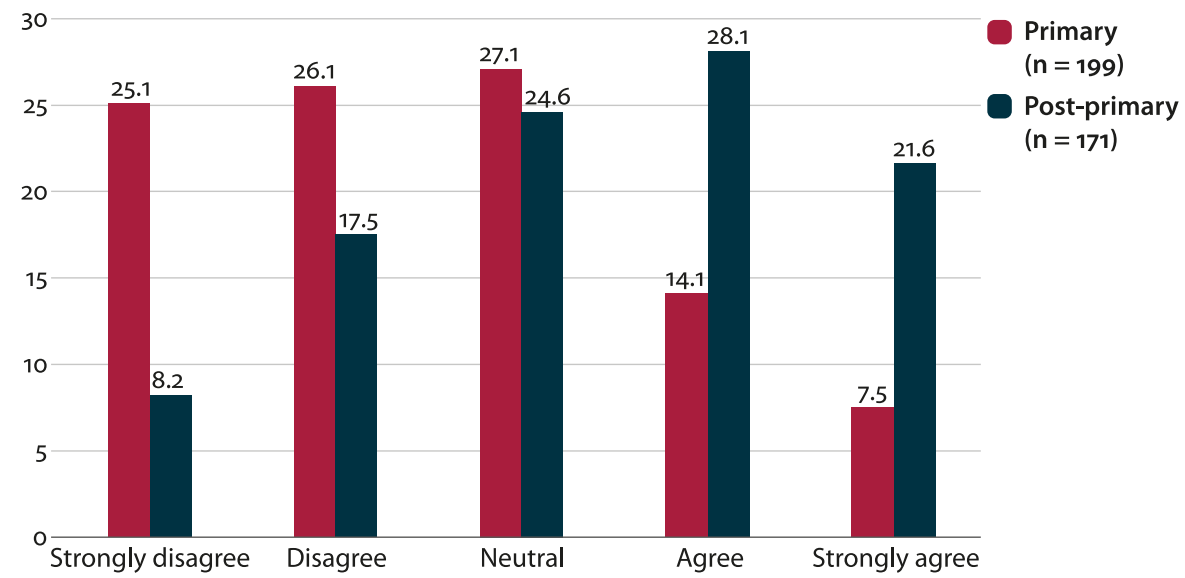

Figure 2. Student responses to the statement: To be honest, I don't make much effort to speak Irish outside of the class when I am at school

The statement "I speak more English than Irish in the school playground" yielded mixed responses also. While $35.5 \%$ of the primary students agreed or strongly agreed with this statement, almost double that number, $70.2 \%$ of postprimary students agreed or strongly agreed (Figure 3), confirming what the previous question highlighted.

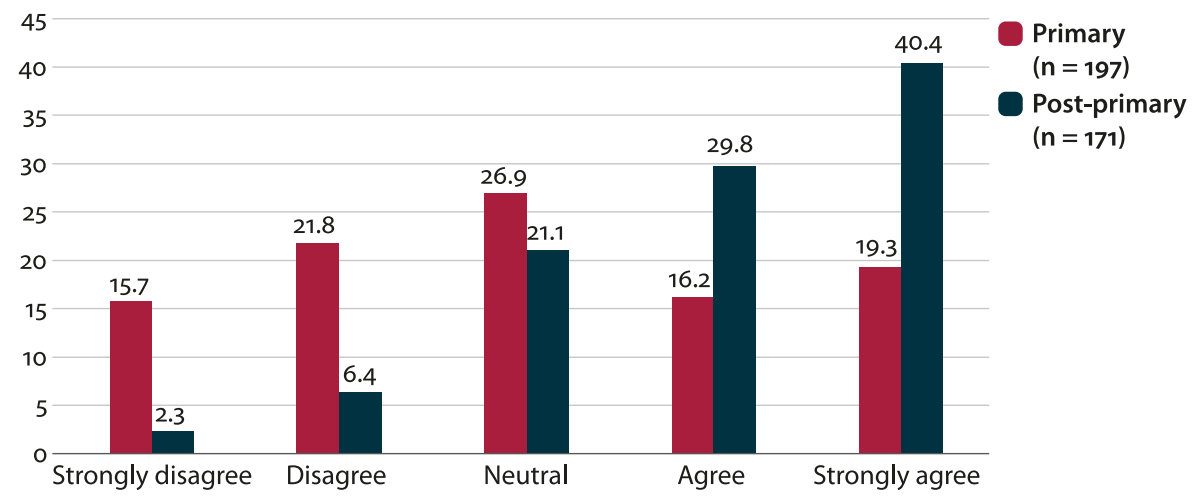

Figure 3. Student responses to the statement: I speak more English than Irish in the school playground

\section{Responses to parents' questions}

A total of 1059 parents responded to the language background and current practices questions across the three studies. Most parents (94.2\%) spoke 'only or mostly English' with their children at home and 5.0\% spoke either an equal mix of English and Irish, mostly Irish, or only Irish with their children (Table 4). 
Table 4. What language(s) do you speak to your children at home?

\begin{tabular}{lcccc}
\hline & $\begin{array}{c}\text { Study A } \\
(n=346)\end{array}$ & $\begin{array}{c}\text { Study B } \\
(n=318)\end{array}$ & $\begin{array}{c}\text { Study C } \\
(n=395)\end{array}$ & $\begin{array}{c}\text { Total } \\
(n=1059)\end{array}$ \\
\hline $\begin{array}{l}\text { English only } \\
\text { English and Irish but mostly } \\
\text { English }\end{array}$ & $41.6 \%$ & $17.3 \%$ & $18.7 \%$ & $25.6 \%$ \\
$\begin{array}{l}\text { An equal mix of English and } \\
\text { Irish }\end{array}$ & $49.4 \%$ & $77.0 \%$ & $78.3 \%$ & $68.6 \%$ \\
$\begin{array}{l}\text { Irish and English but mostly } \\
\text { Irish }\end{array}$ & $2.0 \%$ & $3.5 \%$ & $1.9 \%$ & $3.3 \%$ \\
Irish only & $0.9 \%$ & $0.3 \%$ & $0.7 \%$ & $1.3 \%$ \\
Other language & $1.4 \%$ & $0.6 \%$ & $0.5 \%$ & $0.8 \%$ \\
\hline
\end{tabular}

In relation to the language of the parent's schooling, 107 (10.1\%) of the 1059 had attended a primary or post-primary Irish-medium school. We explored if any correlation existed between parental attendance at an Irish-medium school and parental reports of speaking Irish at home. If we assume no influence of attendance at an Irish-medium school, we would expect 5.4 (5\% of 107) parents who attended Irish-medium schools to speak an equal mix of Irish and English, mostly Irish, or only Irish to their children, with the remaining 101.6 (95\%) parents speaking mostly or only English. However, the actual language practices of the 107 parents, revealed that $13(12.1 \%)$ of them spoke an equal mix of Irish and English, mostly Irish, or only Irish to their children. The remaining 94 $(87.9 \%)$ spoke mostly or only English to their children (Table 5). We found in a chi-squared test that there was significant correlation between the level of Irish spoken by parents in the home and the language medium of the school they attended, $\mathrm{X}^{2}(1, N=1050)=12.54, p<.001$ with a weak effect size $\varphi_{c}=.109, p<.001$.

Table 5. Parental attendance at an Irish-medium school and their language practice with their children

\begin{tabular}{|c|c|c|c|c|}
\hline & \multicolumn{2}{|r|}{ Expected practice } & \multicolumn{2}{|r|}{ Actual practice } \\
\hline & $\begin{array}{l}\text { Speaks } \\
\text { mostly } \\
\text { English }\end{array}$ & $\begin{array}{l}\text { Speaks an equal mix of } \\
\text { Irish and English, } \\
\text { mostly or only Irish }\end{array}$ & $\begin{array}{l}\text { Speaks } \\
\text { mostly } \\
\text { English }\end{array}$ & $\begin{array}{l}\text { Speaks an equal mix of } \\
\text { Irish and English, } \\
\text { mostly or only Irish }\end{array}$ \\
\hline $\begin{array}{l}\text { Irish-medium } \\
\text { primary or post- } \\
\text { primary school } \\
(n=107)\end{array}$ & $\begin{array}{l}101.6 \\
(95 \%)\end{array}$ & $5.4(5 \%)$ & $\begin{array}{c}94 \\
(87.9 \%)\end{array}$ & $13(12.1 \%)$ \\
\hline $\begin{array}{l}\text { English-medium or } \\
\text { other language } \\
\text { school }(n=943)\end{array}$ & $\begin{array}{l}895.4 \\
(95 \%)\end{array}$ & $47.6(5 \%)$ & $\begin{array}{c}903 \\
(95.8 \%)\end{array}$ & $40(4.2 \%)$ \\
\hline
\end{tabular}


Correlations between the student and parental results in study A

In Study A, 346 parents returned completed questions, representing a 56.1\% response rate which was marginally lower than the student response rate. When we conducted a regression analysis on the student scales to explore student scores in relation to parent, student and school characteristics, we found that there was positive correlation between the scores on the 'Parental encouragement to learn Irish' scale and the 'Use of Irish' scale. When we included the school level in the model, we found that primary school parents speak Irish more often to their children than post-primary school parent.

\section{Discussion}

This paper explores the Irish government's education policy in relation to the revival of the Irish language and the promotion of bilingualism since the foundation of the state and critiques the outcome of these policies. With the benefit of hindsight, it can be argued that the policies were unrealistic in terms of what could be achieved in a short timeframe, and there was a misguided belief that language revival could be fostered through education alone.

This legacy of failed policies led to a low point in Irish-medium in the 1970s. The demand from parents for additional Irish-medium schools resulted in considerable growth in the sector throughout both jurisdictions on the island of Ireland. Despite this growth in attendance at Irish medium schools, the intergenerational transmission of the Irish language continues to decline according to census data. Similar findings are seen in other parts of the world where minority languages struggle to compete with major languages. There is growing recognition that education policies alone cannot revive a minority language. In the 20-year Irish language Strategy, the need to support the language in concrete and novel ways is recognised. However, to date little has been achieved in reversing the trends described. The disappointing outcomes in language transmission raises the question as to whether Irish immersion programmes (which frequently exist in a social context that offers little or no opportunity to use the language outside of school) can make any long-term contribution to the transmission of the language. This question informed the studies reported in this paper.

We know that students of immersion education programmes achieve a reasonable level of fluency (capacity), but we know little about the trajectory of their Irish use once they leave the school system. It is our contention that the students' attitudes towards the language and their motivation or the opportunities they get to speak it, play an important role in whether they will continue to use Irish as adults. 
The findings in Study A align with other studies which showed that students in Irish-medium schools have a strong desire to learn Irish, a very positive attitude to learning and using Irish, receive support from their parents to learn Irish and have a positive self-concept of their ability in Irish (Harris \& Murtagh, 1999; Kennedy, 2012). In our study, students also rated their 'Use of Irish' positively, but less so than the other scales. It appears that the most influential factors on children's use of Irish are the amount of Irish spoken in the home and their stage of education, primary or post-primary.

The parental responses revealed that the numbers of parents who spoke a substantial level of Irish to their children at home was low. Nonetheless, it is interesting that $12.1 \%$ of parents who attended Irish-medium schools spoke Irish to their children at least half of the time. This compares to $4.2 \%$ for parents who attended English-medium or other language schools. Thus, parents who themselves attended an Irish-medium school were almost three times more likely to converse in Irish with their own children at least half of the time. These results align with Baker (2003) who claimed that it was very challenging to transfer a minority language acquired in an educational context to other domains outside the school. Even so, it might be possible through planned interventions at school community level to increase the amount of Irish spoken in the home.

While Irish-medium students have very good communicative skills in Irish (Harris et al., 2006; Ó Duibhir, 2009) and some of their parents' self-report good communicative competence (Ó Duibhir et al., 2017), it is an enormous challenge to transfer that competence to home and wider societal use (Darmody \& Daly, 2015; NigUidhir et al., 2016). This is a perennial challenge with minority languages; where students successfully acquire a language but have little or no opportunity to use it outside of the school context (Mac Aogáin, 1990). As maintained by Crystal (2000, p. 154) "Languages need communities in order to live. So, only a community can save an endangered language". Apart from a small number of Irish-language networks, it is difficult to claim that there is an Irish-speaking community in existence outside of the Gaeltacht. The language ability possessed by Irish-medium school students could be utilised to form the nucleus of such a community. The 20-year strategy for Irish recognises the importance of the community in increasing the vitality of the language. Apart from language planning schemes that have commenced in the Gaeltacht, however, little action has taken place to date outside the Gaeltacht to foster the development of Irish language communities. The most encouraging efforts being made to establish Irishlanguage communities outside the Gaeltacht are located in NI where communities in the Falls Road, Belfast, and An Carn in County Derry, are working hard to create such communities. Another noteworthy example is that of $\mathrm{Na}$ Gaeil Óga in Dublin. This is a sports club where the members play Gaelic Football and 
Hurling through the medium of Irish, thus providing opportunities and a context for Irish use among its players. It is suggested by some (Edwards, 2017; Ó Giollagáin \& Charlton, 2015) that such grass-root initiatives provide the best prospect for future language use in the case of minority languages. The Irish situation contrasts with the Basque country, for example, where each school devises its own language plan with short- and long-term objectives under the Ulibarri programme and are supported by teacher support centres (Aldekoa \& Gardner, 2002; Ó Duibhir et al., 2015). The purpose of the Ulibarri programme is to normalise use of the Basque language throughout the school by funding a wide range of extra-curricular events (Zalbide \& Cenoz, 2008). Despite these efforts, normalising the use of Basque in wider society in proving very challenging.

There is a great deal of teaching of Irish in schools in Ireland. Irish-medium students learn Irish to a high standard (Harris et al., 2006) and reap the rewards of this teaching in part due to the amount of contact they have with the language and the opportunities to use what they learn throughout the school day. Their Irish is not without grammatical errors as demonstrated in the analysis of a corpus study by Ó Duibhir (2009). Nonetheless, the students appear to accept that Irish is normalised within the class context. While just over 50\% of primary students recognise that they make an effort to speak Irish outside of the class when they are at school, this falls to one-quarter in post-primary school. The evidence regarding Irish use in the playground where students are not as closely monitored by teachers is that approximately $35 \%$ of primary and $70 \%$ of post-primary students speak more English than Irish. This may indicate that Irish is not accepted as being normalised in the context of the playground when not monitored closely by authority figures. This finding is in keeping with the language behaviour of Gaeltacht teenagers who use Irish more often in contexts where authority figures are present (Ó Giollagáin et al., 2007).

It could be argued that the primary students take greater heed of the exhortations of their teachers to use Irish outside of class, and that post-primary students are influenced more by their peer group and the norm of socialising through English. Students in Ó Cathalláin's (2011) study of Irish-medium schools also reported resistance to the requirement to speak Irish. These findings are in keeping with evidence from Wales where students in Welsh-medium schools reported greater use of English when the teacher was not present (Thomas, Apolloni, \& Lewis, 2014). We need to be careful in our interpretation of these figures, however, as other research (Mac Gréil \& Rhatigan, 2009) has shown that many adults had a more positive attitude to Irish in adulthood than they had when they were attending school. When Gaeltacht teenagers were asked what language, they would use to raise their children (should they have children), 
$71 \%$ said they would raise them through Irish (Ó Giollagáin et al., 2007). This is despite the fact that the vast majority socialised through English.

While the growth of a ground-up Irish-medium school movement may be one of the most positive advances in the effort to revitalise Irish, its impact appears to be confined so far to the domain of the school. It could be argued that the issue of language use outside the education context is the $\mathrm{X}$ factor that has been missing from Irish revitalisation efforts. This has been the pattern since the foundation of the Irish Free State (Walsh, 2012). The neoliberal policies of successive Irish Governments since 1973 have made unreasonable demands on the education system and ignored community initiatives and as a result the language has been marginalised. If Irish-medium school students are to convert their ability in Irish to become new speakers of Irish, they will need greater opportunities than those currently available to use Irish in out-of-school and post-school contexts.

A combined effort by Irish-medium school communities supported by state agencies is required to establish the greatest prospect of achieving this. In the context of minority languages, the state has a role in terms of language planning to create the conditions where capacity, opportunity and desire are nurtured (Grin, 2003). There are proposals to create Irish language and cultural centres in Dublin and other towns and cities as part of the Project Ireland 2040 (Government of Ireland, 2018) which offer some hope. We can see evidence of a language planning process in the Gaeltacht where local committees have been charged with the task of developing language plans for their area under the Gaeltacht Act 2012 (Department of Culture, Heritage and the Gaeltacht, 2012). Many committees have produced plans but are dissatisfied with the level of funding available to implement the plans. The Government has effectively delegated the future of Irish in Gaeltacht communities to the local population without the provision of adequate resources. A sometime hidden consequence of under-resourced community initiatives is the risk that if communities fail to implement language plans to stop the decline of Irish, the Government can make the local communities accountable, absolving themselves of responsibility.

Returning to Irish-medium schools and how to maximise their effect in society, parents who wish their children to use Irish need to maximise the opportunities for their children to speak Irish in the home. This is best done by the parents using whatever Irish they have. Parents undoubtedly need support if this is to happen. Both students and parents in the studies discussed here revealed very positive attitudes towards Irish. These positive attitudes are not translated into the active use of Irish. Normalising a minority language where the main exposure to the language is confined to the school context is extremely challenging (Thomas, Apolloni, \& Lewis, 2014). Consequently, children may be acquiring high levels of competence in a language that they will not actively use as adults. These find- 
ings highlight the importance of the learning environment in providing a context where there is rich exposure and opportunities to use the target language. A major challenge in promoting greater use of Irish in society, however, is to transfer use of Irish from the immersion school to the home and community.

\section{Conclusion}

In the opening section of this paper we charted the decline and revitalisation of Irish. The attempts to revitalise Irish are characterised by issues of heritage and identity with the emphasis placed on enabling children to speak Irish and generating new speakers of Irish. While Irish-medium schools are proving very successful in educating proficient speakers of Irish, they are unlikely on their own to create the conditions where these students will become active users of Irish. The parentled movement that established the Irish-medium schools needs to be extended now to embrace this challenge. If the Irish government is serious about the proposals contained in the 20-year Strategy (Government of Ireland, 2010) and Project Ireland 2040 (Government of Ireland, 2018) it needs to provide adequate funds for the implementation of language plans in the Gaeltacht and to create safe spaces in communities outside the Gaeltacht possibly aligned with Irish-medium school communities. When successful community networks are set up and operate through the medium of Irish, economic activity may flow from them which would provide additional stimulus to the promotion of the language.

\section{References}

Aldekoa, J., \& Gardner, N. (2002). Turning knowledge of Basque into use: Normalisation plans for schools. International Journal of Bilingual Education and Bilingualism, 5(6), 339-354. https://doi.org/10.1080/13670050208667766

Baker, C. (2003). Education as a site of language contact. Annual Review of Applied Linguistics, 23, 95-112. https://doi.org/10.1017/S0267190503000217

Central Statistics Office. (1932). Census of population 1926: Volume 8 - Irish language. Dublin: Stationery Office.

Central Statistics Office. (2017). Census 2016 summary results - Part 1. Retrieved from: $<$ https://www.cso.ie/en/media/csoie/releasespublications/documents/population/2017/7 ._The_Irish_language.pdf $>$ (17 April, 2018).

Crystal, D. (2000). Language death. Cambridge: Cambridge University Press. https://doi.org/10.1017/CBO9781139106856

Darmody, M., \& Daly, T. (2015). Attitudes towards the Irish Language on the island of Ireland. Dublin: Economic and Social Research Institute. 
Department of Culture Heritage and the Gaeltacht. (2012). The Gaeltacht Act 2012. Retrieved from: <https://www.chg.gov.ie/app/uploads/2015/o7/Gaeltacht-Act-20121.pdf> (18 April, 2018).

Dörnyei, Z. (2009). Individual differences: Interplay of learner characteristics and learning environment. Language Learning, 59, 230-248. https://doi.org/10.1111/j.1467-9922.2009.00542.x

Doyle, A. (2015). A history of the Irish language: From the Norman invasion to independence. Oxford: Oxford University Press.

Edwards, J. (2017). Celtic languages and sociolinguistics: A very brief overview of pertinent issues. Language, Culture and Curriculum, 30(1), 13-31. https://doi.org/10.1080/07908318.2016.1230618

Fishman, J.A. (2013). Language maintenance, language shift, and reversing language shift. In T. K. Bhatia \& W.C. Ritchie (Eds.), Handbook of bilingualism and multilingualism (pp. 466-494). Chichester: Wiley \& Sons.

Gardner, R.C. (1985). The attitude/motivation test battery: Technical report. London, Ontario: University of Western Ontario.

Government of Ireland. (2010). 20-year strategy for the Irish language 2010-2030. Dublin: Stationery Office.

Government of Ireland. (2018). Project Ireland 2040. Dublin: Stationery Office.

Grin, F. (2003). Language policy evaluation and the European Charter for Regional or Minority Languages. Houndmills: Palgrave Macmillan. https://doi.org/10.1057/9780230502666

Harris, J., \& Conway, M. (2002). Modern languages in Irish primary schools: An evaluation of the National Pilot Project. Dublin: Institiúid Teangeolaíochta Éireann.

Harris, J., Forde, P., Archer, P., Nic Fhearaile, S., \& O'Gorman, M. (2006). An Ghaeilge sna bunscoileanna: Treochtaí náisiúnta fadtéarmacha in inniúlacht. Baile Átha Cliath: An Roinn Oideachais agus Eolaíochta.

Harris, J., \& Murtagh, L. (1999). Teaching and learning Irish in primary school: A review of research and development. Dublin: Institiúid Teangeolaíochta Éireann.

Hornsby, M. (2017). Finding an ideological niche for new speakers in a minoritised language community. Language, Culture and Curriculum, 30(1), 91-104. https://doi.org/10.1080/07908318.2016.1230622

Kennedy, I.A. (2012). Irish medium education: Cognitive skills, linguistic skills, and attitudes towards Irish (Unpublished doctoral dissertation). Bangor University.

Lasagabaster, D., \& Sierra, J.M. (2010). Immersion and CLIL in English: More differences than similarities. ELT Journal, 64(4), 367-375. https://doi.org/10.1093/elt/ccpo82

Mac Aogáin, E. (1990). Teaching Irish in the schools: Towards a policy for 1992. Dublin: Linguistics Institute of Ireland.

Mac Gréil, M., \& Rhatigan, F. (2009). The Irish language and the Irish people. Maynooth: Department of Sociology, National University of Ireland Maynooth.

McAdory, S.E., \& Janmaat, J. G. (2015). Trends in Irish-medium education in the Republic of Ireland and Northern Ireland since 1920: Shifting agents and explanations. Journal of Multilingual and Multicultural Development, 36(5), 528-543. https://doi.org/10.1080/01434632.2014.969273

Murtagh, L. (2007). Out-of-school use of Irish: Motivation and proficiency in immersion and subject only post-primary programmes. International Journal of Bilingual Education and Bilingualism, 10(4), 428-453. https://doi.org/10.2167/beb453.0 
Ní Chlochasaigh, K., Shiel, G., \& Ó Duibhir, P. (2018). Tionchar an tumoideachais ar dhaltaí $i$ scoileanna lán-Ghaeilge le stádas DEIS: Gnóthachtáil, dearcthaí agus dúshláin [The impact of immersion education on students in Irish-medium DEIS schools: Achievement, perspectives and challenges]. Paper presented at the The Second AllIreland Research Conference on Immersion Education, Mary Immaculate College, Limerick.

NigUidhir, G., Ó Cathalláin, S., \& Ó Duibhir, P. (2016). Tuismitheoirí ina ngníomhairí in earnáil an Ghaeloideachais. [Parents as agents in the Irish-medium sector] COMHARTaighde, 2(1), 2-28. https://doi.org/10.18669/ct.2016.06

Ní Thuairisg, L., \& Ó Duibhir, P. (2016). An leanúnachas ón mbunscoil go dtí an iar-bhunscoil lán-Ghaeilge i bPoblacht na hÉireann [Pupil progression from Irish-medium primary to post-primary in the Republic of Ireland]. Retrieved from: <http://www.gaelscoileanna.ie /files/An-Lean--nachas-on-mbunscoil-go-dt---an-iar-bhunscoil-1--n-Ghaeilge-_MF-2016 .pdf> (25 May, 2018).

Ó Buachalla, S. (1984). Educational policy and the role of the Irish language from 1831 to 1981. European Journal of Education, 19(1), 75-92. https://doi.org/10.2307/1503260

Ó Cathalláin, S. (2011). Early literacy in all-Irish immersion primary schools: A microethnographic case study of storybook reading events in Irish and English (Unpublished doctorial dissertation). University of Stirling.

O'Connell, T. J. (1968). History of the Irish National Teachers' Organisation, 1868-1968. Dublin: Irish National Teachers' Organisation.

Ó Duibhir, P. (2009). The spoken Irish of sixth-class pupils in Irish immersion schools (Unpublished dotoral dissertation). Trinity College, Dublin.

Ó Duibhir, P. (2010). "It's only a language.": The attitudes and motivation of Irish-medium education students to the Irish language. In W. Hutchinson \& C. Ní Ríordáin (Eds.), Language issues: Ireland, France, Spain (pp. 121-138). Brussels: Peter Lang.

Ó Duibhir, P. (2011). 'I thought that we had good Irish': Irish immersion students' insights into their target language use. In D. J. Tedick, D. Christian, \& T. Williams Fortune (Eds.), Immersion education: Practices, policies, possibilities (pp. 145-165). Bristol: Multilingual Matters.

Ó Duibhir, P. (2012). Cúrsaí oideachais agus Straitéis 2o Bliain don Ghaeilge [Education matters and the 20-year Strategy for Irish]. In C. Lenoach, C. Ó Giollagáin, \& B. Ó Curnáin (Eds.), An chonair chaoch: An mionteangachas sa dátheangachas (pp. 269-283). Galway: Leabhar Breac.

Ó Duibhir, P. (2018). Immersion education: Lessons from a minority language context. Bristol: Multilingual Matters. https://doi.org/10.21832/ODUIBH9832

Ó Duibhir, P., Ní Chuaig, N., Ní Thuairisg, L., \& Ó Brolcháin, C. (2015). Educational provision through minority languages: Review of international research. Retrieved from: <https:// www.education.ie/en/Press-Events/Events/Gaeltacht-Education-Policy-Proposals /Education-Provision-through-Minority-Languages_Review-of-International-Research _May-2015.pdf> (16 April, 2018).

Ó Duibhir, P., Ó Cathalláin, S., NigUidhir, G., Ní Thuairisg, L., \& Cosgrove, J. (2017). An analysis of models of provision for Irish-medium schools. Retrieved from: <https://www .forasnagaeilge.ie/wp-content/uploads/2018/o6/4f2553653522aa6ocd8dcca85b8b5f5o.pdf> (16 April, 2018).

Ó Giollagáin, C., \& Charlton, M. (2015). Update on the comprehensive linguistic study on the use of Irish in the Gaeltacht: 2006-2011. Galway: Údarás na Gaeltachta. 
Ó Giollagáin, C., Mac Donnacha, S., Ní Chualáin, F., Ní Shéaghdha, A., \& O’Brien, M. (2007). Staidéar cuimsitheach teangeolaíoch ar úsáid na Gaeilge sa Ghaeltacht: Príomhthátal agus moltaí. Dublin: Department of Community, Rural and Gaeltacht Affairs.

Ó Laoire, M. (2006). Múineadh na Gaeilge agus na nuatheangacha eile: Polasaí agus pleanáil teanga. In A. Gallagher \& M. Ó Laoire (Eds.), Language education in Ireland: Current practice and future needs (pp. 1-23). Dublin: Irish Association for Applied Linguistics.

Ó Murchadha, N.P., \& Migge, B. (2017). Support, transmission, education and target varieties in the Celtic languages: An overview. Language, Culture and Curriculum, 30(1), 1-12. https://doi.org/10.1080/07908318.2016.1230621

Ó Riagáin, P. (2000). Irish language production and reproduction 1981-1996. In J.A. Fishman (Ed.), Can threatened languages be saved? Reversing language shift, revisited: A 21st century perspective (pp. 195-214). Clevedon: Multilingual Matters.

O'Rourke, B., \& Walsh, J. (2015). New speakers of Irish: Shifting boundaries across time and space. International Journal of the Sociology of Language, 231, 63-83. https://doi.org/10.1515/ijsl-2014-0032

Pujolar, J., \& Gonzàlez, I. (2013). Linguistic 'mudes' and the de-ethnicization of language choice in Catalonia. International Journal of Bilingual Education and Bilingualism, 16(2), 138-152. https://doi.org/10.1080/13670050.2012.720664

Shah, S., \& Brenzinger, M. (2018). The role of teaching in language revival and revitalization movements. Annual Review of Applied Linguistics 38, 201-208. https://doi.org/10.1017/S0267190518000089

Thomas, E. M., Apolloni, D., \& Lewis, G. (2014). The learner's voice: Exploring bilingual children's selective language use and perceptions of minority language competence. Language and Education, 28(4), 340-361. https://doi.org/10.1080/09500782.2013.870195

Walsh, J., \& O’Rourke, B. (2015). Mudes teangeolaíocha agus nuachainteoirí na Gaeilge. COMHARTaighde, 1. Retrieved from: <http://www.comhartaighde.com/eagrain/1/walshorourke/walsh-orourke2015.pdf>. https://doi.org/10.18669/ct.2015.09 (26 November, 2015).

Walsh, J., O’Rourke, B., \& Rowland, H. (2015). Tuarascáil taighde ar nuachainteoirí na Gaeilge. Baile Átha Cliath: Foras na Gaeilge.

Walsh, T. (2012). Primary education in Ireland, 1897-1990: Curriculum and context. Oxford: Peter Lang. https://doi.org/10.3726/978-3-0353-0298-1

Walsh, T. (2016). The national system of education, 1831-200o. In B. Walsh (Ed.), Essays in the history of Irish education (pp. 7-43). Houndmills: Palgrave Macmillan.

Wolf, N.M. (2014). An Irish-speaking island: State, religion, community, and the linguistic landscape in Ireland, 1770-1870. Madison, WI: The University of Wisconsin Press.

Zalbide, M., \& Cenoz, J. (2008). Bilingual education in the Basque autonomous community: Achievements and challenges. Language, Culture and Curriculum, 21(1), 5-20. https://doi.org/10.2167/lcc339.0 


\section{Appendix A. Attitude Motivation Test Battery (AMTB)}

The AMTB was administered in Irish - translation provided here. The items have been grouped by scale but were presented in numerical order to the students.

\section{Ceistneoir an dalta (Student questionnaire)}

Scoil (School)

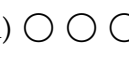

$$
\begin{array}{ccc}
\text { Rang } 5 & \text { Rang } 7 & \text { Bliain 4 4th Year } \\
\text { 5th Class } & \text { 7th Class } & \text { (ROI) } \\
\text { (ROI) } \quad(\mathrm{NI}) &
\end{array}
$$

i. Cén rang ina bhfuil tú? What class are you in?

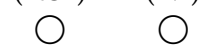

ii. An buachaill nó cailín tú? Are you a boy or a girl?

iii. Cén aois thú How old are you?

$$
\begin{array}{cc}
\begin{array}{c}
\text { Buachaill } \\
\text { (Boy) }
\end{array} & \text { Cailín } \\
\text { (Girl) }
\end{array}
$$

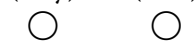

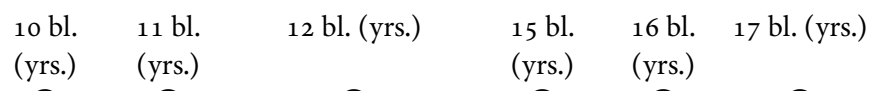

(yrs.) (yrs.)

$\begin{array}{cccccc}\begin{array}{c}\text { Gaeilge } \\ \text { amháin }\end{array} & \begin{array}{c}\text { Gaeilge } \\ \text { den }\end{array} & \begin{array}{c}\text { Meascán cothrom } \\ \text { de Ghaeilge agus }\end{array} & \begin{array}{c}\text { Béarla } \\ \text { den chuid }\end{array} & \begin{array}{c}\text { Béarla } \\ \text { amháin }\end{array} & \begin{array}{c}\text { Teanga eile } \\ \text { (Language }\end{array} \\ \text { (Irish } & \text { chuid is } & \text { Bhéarla (Equal mix } & \text { is mó } & \text { (English } & \text { other than } \\ \text { only) } & \text { mó } & \text { of Irish and } & \text { (Mostly } & \text { only) } & \text { Irish or } \\ & \text { (Mostly } & \text { English) } & \text { English) } & & \text { English) }\end{array}$

iv. Cad é an gnáththeanga a labhraíonn ( tú sa bhaile? What is your usual home language?

Ceisteanna cleachta (Practice questions)

1 2 3 45

Easaontaím go Easaontaím Neodrach Aontaím Aontaím go mór Strongly beagáinín Neutral beagáinín mór disagree Disagree Agree Strongly

A. Is fearr liom banana ná úll. (I prefer bananas to apples.)

B. Is fuath liom sceallóga. (I hate chips.)

C. Tá laethanta saoire an tsamhraidh ró-fhada. (Summer holidays are too long.) 
Fonn foghlama Gaeilge (Desire to learn Irish) (6 mhír/items)

11. Dá mbeadh seans agam Gaeilge a labhairt tar éis am scoile, ba mhaith liom iarracht a dhéanamh í a labhairt.

26. Ba mhaith liom freastal ar Chúrsa Samhraidh Ghaeilge.

16. I gcomparáid le hábhair scoile eile mar an Mhatamaitic agus léitheoireacht an Bhéarla, ní maith liom an Ghaeilge mórán.

21. Dá mbeadh teaghlaigh ina labhraítear Gaeilge ina gcónaí in aice liomsa, ba mhaith liom labhairt leo i nGaeilge.

30. Ba mhaith liom a bheith in ann Gaeilge a labhairt cosúil le cainteoir dúchais.

8. Ba mhaith liom níos lú ama a chaitheamh ag foghlaim na Gaeilge ar scoil. $\bigcirc \bigcirc \bigcirc \bigcirc$ If there was a chance to speak Irish outside school, I would like to try to speak it.

$\bigcirc \bigcirc \bigcirc \bigcirc$ I would like to go to a Summer course in Irish.

$\bigcirc \bigcirc \bigcirc \bigcirc$ Compared to subjects like Maths and English reading, I don't like Irish very much.

$\bigcirc \bigcirc \bigcirc \bigcirc$ If there were Irish-speaking families living near me, I would like to speak Irish to them.

$\bigcirc \bigcirc \bigcirc \bigcirc$ I would like to be able to speak Irish like a native speaker. I would like to spend less time learning Irish at school.

Dearcadh i leith foghlaim na Gaeilge (Attitude to learning Irish) (7 mír/items)

4. Is cur amú ama é a bheith ag déanamh staidéir ar an nGaeilge ar scoil.

7. Nuair a fhágfaidh mé an scoil, éireoidh mé as a bheith ag déanamh staidéir ar an nGaeilge ar fad toisc nach bhfuil aon suim agam inti.

11. Bainim an-taitneamh ar fad as a bheith ag déanamh staidéir ar an nGaeilge ar scoil.

17. Is ábhar scoile tábhachtach í an Ghaeilge.

24. Is fuath liom a bheith ag foghlaim na Gaeilge $\bigcirc \bigcirc \bigcirc \bigcirc \bigcirc$ I hate learning Irish at school. ar scoil.

31. Tá foghlaim na Gaeilge tábhachtach ach tá foghlaim an Bhéarla níos tábhachtaí.

2. Ba mhaith liom an oiread Gaeilge agus is féidir liom a fhoghlaim. $\bigcirc \bigcirc \bigcirc \bigcirc$ Learning Irish in school is a waste of time.

When I leave school, I will give up learning Irish completely because I am not interested in it.

I really enjoy learning Irish.

Irish is an important school subject.

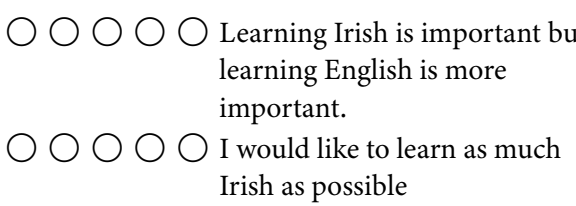

Spreagadh ó thuismitheoirí (Parental encouragement) ( 5 mhír/items)

1. Déanann mo thuismitheoirí (chaomhnóirí) iarracht cabhair a thabhairt dom le mo chuid Gaeilge.

5. Ceapann mo thuismitheoirí gur chóir dom an Ghaeilge a fhoghlaim, toisc go bhfuil cónaí orainn in Éirinn.

15. Is minic a deir mo thuismitheoirí liom a thábhachtaí is a bheidh an Ghaeilge dom nuair a fhágfaidh mé an scoil.
My parents try to help me with my Irish.

$\bigcirc \bigcirc \bigcirc \bigcirc$ My parents feel that because we live in Ireland, I should study Irish.

$\bigcirc \bigcirc \bigcirc \bigcirc$ My parents often tell me how important Irish will be for me when I leave school. 
20. Molann mo thuismitheoirí go mór dom oibriú go dian ar an nGaeilge.

27. Spreagann mo thuismitheoirí mé mo chuid Gaeilge a chleachtadh an oiread agus is féidir. $\bigcirc \bigcirc \bigcirc \bigcirc$ My parents really encourage me to work hard at my Irish.

My parents encourage me to improve my Irish as much as possible.

1. Féinchoincheap ar chumas sa Ghaeilge (Irish-ability self-concept) (6 mhír/items)

18. Dá dtabharfainn cuairt ar an nGaeltacht, bheinn ábalta treoir a lorg agus a leanúint i nGaeilge chun mo bhealach a dhéanamh.

28. Tá sé deacair an Ghaeilge a labhairt an tam go léir ar scoil.

6. Cheapfadh cainteoir dúchais go raibh Gaeilge an-mhaith agam.

22. Spreagann múinteoirí na scoile mé le Gaeilge a labhairt i gcónaí is mé ar scoil.

23. Tuigim cainteoirí dúchais gan aon fhadhb $\bigcirc \bigcirc \bigcirc \bigcirc \bigcirc$ I understand native speakers nuair a bhíonn siad ag caint as Gaeilge.

14. Labhraím Gaeilge cosúil le cainteoir dúchais.

2. Úsáid na Gaeilge (Use of Irish) (13 mír/items)

3. Léim leabhair i nGaeilge uaireanta nach leabhair scoile iad.
$\bigcirc \bigcirc \bigcirc \bigcirc$ If I visited the Gaeltacht I would be able to look for and follow directions to make my way.

$\bigcirc \bigcirc \bigcirc \bigcirc$ It is difficult to speak Irish all the time at school.

$\bigcirc \bigcirc \bigcirc \bigcirc$ A native Irish speaker would think that my Irish was very good.

$\bigcirc \bigcirc \bigcirc \bigcirc$ My teachers encourage me to always speak Irish when I am at school. without difficulty when they are speaking Irish.

$\bigcirc \bigcirc \bigcirc \mathrm{I}$ speak Irish like a native speaker.

$\bigcirc \bigcirc \bigcirc \bigcirc \bigcirc$ I sometimes read books in Irish that are not schoolbooks.

35. Le bheith fírinneach, ní dhéanaim mórán iarrachta an Ghaeilge a labhairt lasmuigh den rang nuair a bhím ar scoil.

32. Is rud tábhachtach dom é Gaeilge a labhairt i gcónaí nuair a bhím ag caint le mo chairde ar scoil.

$\bigcirc \bigcirc \bigcirc \bigcirc$ To be honest, I don't really try very hard to learn Irish at school.

33. Labhraím níos mó Béarla ná Gaeilge i gclós na scoile.

34. Tá sé i bhfad níos deacra orm Gaeilge a labhairt ná Béarla.

29. Bheinn míchompordach ag labhairt Gaeilge le mo chairde scoile taobh amuigh d'am agus d'imeachtaí scoile.

9. Tuigim go ndéanaim botúin uaireanta nuair a bhím ag labhairt Gaeilge ach bheadh an iomarca trioblóide ann iad a cheartú.

12. Bím míchompordach nuair a labhraítear liom as Gaeilge taobh amuigh den scoil.

It is important for me to always speak Irish when I am speaking with my friends at school.

$\bigcirc \bigcirc \bigcirc \bigcirc$ I speak more English than Irish in the school playground.

$\bigcirc \bigcirc \bigcirc \bigcirc$ It is much more difficult for me to speak Irish than English.

$\bigcirc \bigcirc \bigcirc \bigcirc$ I would be uncomfortable speaking Irish to my school friends outside of school and school activities.

$\begin{aligned} \bigcirc \bigcirc \bigcirc & \text { I know that I make mistakes } \\ & \text { when I am speaking Irish but it } \\ & \text { would be too much trouble to } \\ & \text { correct them. } \\ & \text { I am uncomfortable when Irish } \\ & \text { is spoken to me outside of } \\ & \text { school. }\end{aligned}$


13. Is fearr liom Gaeilge ná Béarla a labhairt le mo chairde ag am sosa.

19. B'fhearr liom Matamaitic a fhoghlaim trí Bhéarla seachas trí Ghaeilge.

25. Labhraím Gaeilge go minic lasmuigh d'am agus d'imeachtaí scoile.

36 Is fuath liom é nuair a labhraíonn nó nuair a dhéanann mo thuismitheoir iarracht Gaeilge a labhairt liom sa bhaile.

37 Níl aon leabhair ar fáil as Gaeilge atá suimiúil le léamh. $\bigcirc \bigcirc \bigcirc \bigcirc$ I prefer to speak Irish rather than English to my friends at break time.

$\bigcirc \bigcirc \bigcirc \bigcirc$ I would prefer to learn Maths through English than through Irish.

$\bigcirc \bigcirc \bigcirc \bigcirc$ I often speak Irish outside of school and school activities.

$\bigcirc \bigcirc \bigcirc \bigcirc$ I hate it when my parent speaks to me or tries to speak to me in Irish at home.

$\bigcirc \bigcirc \bigcirc \bigcirc$ There are no interesting books available to read in Irish.

\section{Address for correspondence}

Pádraig Ó Duibhir

Dublin City University

Institute of Education

DCU St Patrick's Campus

Drumcondra Dublin D9

Ireland

padraig.oduibhir@dcu.ie

\section{Co-author information}

\section{Laoise Ní Thuairisg}

School of Language, Literacy and Early Childhood Education

DCU Institute of Education

Dublin City University

laoise.nithuairisg@dcu.ie 